\section{Studia \\ z Filologii Polskiej \\ i Słowiańskiej}

DOI: $10.11649 /$ sfps.2350
Studia z Filologii Polskiej i Słowiańskiej, 56

Warszawa 2021

Article No. 2350

\section{Citation:}

Kuryłowicz, B., \& Szamryk, K. K. (2021). Linguistic and cultural perceptions of selected occupations in eighteenth-century proverbs (on the basis of Nowy dykcjonarz by Michał Abraham Troc). Studia z Filologii Polskiej i Słowiańskiej, 56, Article 2350. https://doi.org/10.11649/sfps.2350

\author{
Beata Kuryłowicz \\ (University of Białystok) \\ Konrad Kazimierz Szamryk \\ (University of Białystok)
}

\title{
Linguistic and Cultural Perceptions of Selected Occupations in Eighteenth-Century Proverbs (on the Basis of Nowy dykcjonarz by Michał Abraham Troc)*
}

\section{Introduction}

The aim of this article is to present the content of the historical dictionary entitled Nowy dykcjonarz, to jest Mownik polsko-niemiecko-francuski [A New Dictionary, That Is, A Polish-German-French Phrase-Book] (published in Leipzig in 1764) as a valuable source for the reconstruction of the historical linguistic

* The project is financed from a grant received from the Polish Ministry of Science and Higher Education under the Regional Initiative of Excellence programme for the years 2019-2022, project number 009/RID/2018/19, the amount of funding: PLN 8,791,222.00.

This is an Open Access article distributed under the terms of the Creative Commons Attribution 3.0 PL License (creativecommons.org/licenses/by/3.0/pl/), which permits redistribution, commercial and non-commercial, provided that the article is properly cited. (c) The Author(s) 2021.

Publisher: Institute of Slavic Studies, Polish Academy of Sciences

[Wydawca: Instytut Slawistyki Polskiej Akademii Nauk] 
picture of occupations, and thus a source to reconstruct former standard patterns of thinking about the world in terms of categories and values typical of Polish speakers from past centuries. The observations in question are based on proverbs extracted from this dictionary which contain selected names of occupations or references made to perceptions of people who performed them, presented in a cultural context.

This paper is not a mere comprehensive description of the reality of Polish life in the eighteenth century as seen through language. The aim is to reproduce a small fragment of the worldview and to present possibilities offered by the study of linguistic material contained in historical lexicographic sources, with a focus on proverbs.

\section{Linguistic worldview in proverbs}

This paper follows the trends of contemporary linguistic studies, especially cultural linguistics, which examine interactions between language, culture and thought (cf. Fillmore, 1979, 1982, 1985; Lakoff, 1986a, 1986b; Langacker, 2008; Taylor, 1989). In this approach, language is not a mere communication tool and a means of expression, but also an element of broadly understood culture (cf. Anusiewicz, 1994).

One of the main concepts of contemporary semantics and cognition theory is linguistic worldview (cf. Allwood, 2004; Underhill, 2009). According to the latest definition by Jerzy Bartmiński, it is

a language-entrenched interpretation of reality, which can be expressed in the form of judgments about the world, people, things or events. It is an interpretation, not a reflection [...]. The interpretation is a result of subjective perception and conceptualization of reality performed by the speakers of a given language; thus, it is clearly subjective and anthropocentric but also intersubjective (social). [...] It influences [...] the perception and understanding of the social situation by a member of the community. (Bartmiński, 2012, p. 23)

It is worth noting that proverbs serve an important function in linguistic worldview reconstruction (cf. Jędrzejko, 2015; Młynarczyk, 2013; Stefanović, 2009). They can be perceived as a special language form in which conventional knowledge of the world is contained. Their synthetic formula makes it possible to express, in a simple and universal way, the content essential and significant for a given linguistic and cultural community. Proverbs arise from the everyday speech 
of people belonging to all social strata, classes and occupations (Szpila, 2003; Wyżkiewicz-Maksimow, 2012, p. 21); hence, they expose both intersubjective and colloquial visions of reality. They are the carrier of common-sense knowledge accepted by the general public (cf. Hołówka, 1986).

Proverbs are both a document of tradition and culture, in which timeless content has been coded, as well as a testimony of a specific time - the period in which they were created and formed, a living substance of a language, the Polish language in this particular study. Proverbs accumulate knowledge about the world from different eras. Furthermore, they tell us the most about various aspects of the life of language users who had actually known and used them. Due to their strong roots in culture and language, proverbs expose highly conventionalized or even stereotyped semantic content. They are indispensable in establishing systemic connotations - those components of meaning that are expressive linguistically and socially stabilized. In the structure of a lexical unit, they form a layer of semantic features located close to the nucleus: lexical meaning (cf. Tokarski, 2013, pp. 217-246). Presentation of these stable, textually invariant components is particularly important in learning the historical aspects of the linguistic worldview. However, their reconstruction is based on a small number of source data, as diachronic studies on linguistic worldview cannot make use of surveys. Furthermore, the lexicographic definitions that inform about the features most strongly associated with the word form are utterly insufficient.

Moreover, it should be emphasized that this study focuses on proverbs proper, which differ from idiomatic expressions in their autonomy in terms of content and aphoristic character (Skorupka, 1985, pp. 363-364).

\section{Nowy dykcjonarz by Michał Abraham Troc and its proverbs}

In the opinion of Polish scholar Bogdan Walczak (1994, pp. 55-56), Nowy $d y k c j o n a r z$ by Michał Abraham Troc is one of the two greatest and most important achievements of eighteenth-century Polish lexicography (along with the dictionary by Danet-Kola). The work contains an abundant collection of eighteenth-century vocabulary (with about 45,500 entries). It is, therefore, a significant source of the history of Polish vocabulary, phraseology and paremiology. The value of Nowy dykcjonarz has been recognized by linguists; as a result, several stud- 
ies have been based on this dictionary and considered the following topics: the nautical vocabulary (Iwanowska, 1986, 1991a), the lexicographer himself (Iwanowska, 1989a, 1989b 1990, 1993b), his lexicographic techniques (Iwanowska, 1994; Urbańczyk, 1979, pp. 292-299; Walczak, 1994, pp. 45-57) and his impact on the scholarly culture of Poland in the eighteenth century (Iwanowska, 1993a). Additionally, other studies based on Nowy dykcjonarz enabled exploring the dictionary as a source tor the reconstruction of former ways of everyday thinking and perceiving reality (Puzynina, 1993; Siekierska, 1992). Finally, a considerable part of the Polish-language material in Nowy dykcjonarz consists of proverbs. About 800 Polish proverbs have been extracted from this dictionary and analysed in several articles (Kuryłowicz, 2014, 2016, 2017, 2018). Therefore, there is no doubt that Nowy dykcjonarz is an interesting and inspiring source of information on Polish cultural reality through proverbs.

The proverbs recorded in Nowy dykcjonarz represent almost all areas of life as it was in the period, realities of everyday human existence as well as material products of human activity, elements of the living and inanimate world, and phenomena of spiritual culture. Through their analysis we are able to reconstruct the ways of thinking about the world which were current among eighteenth-century speakers of the language, including their judgments, beliefs and values.

It should, however, be noted at the outset that particular aspects of the indicated spheres, which are reflected in lexical units forming thematic circles, are exposed in the dictionary to various degrees: some have strong representation (many examples of use, including phraseological units and proverbs), others are very poorly or even not at all illustrated with language material.

\section{Occupations through the lens of proverbs}

The choice of the material (i.e. proverbs where occupations are one of the elements) is motivated by the need to show characteristic properties of the linguistic perception of the world emerging from Nowy dykcjonarz. It reveals the relationship between the frequency of occurrence of different proverb categories in the dictionary, compared to the methodological concept of the dictionary and the perspective ${ }^{1}$ of the world adopted by the author.

1 The term perspective is used here in the sense in which it is used in Langacker's works. In line with Langacker's language model, selection of a perspective is used for the purposes of selection of 


\subsection{Cobbler}

Proverbs using names of occupations of the period form a scarce, yet an interesting part of the material collected by Troc. They include documented examples which, in most instances, reveal a pejorative valuation of a shoemaker $($ szewc), as illustrated by the proverb noted in two variants: Szewcze, patrzaj twego rzemiosta ${ }^{2}$ [lit. Shoemaker, mind your own craft] and Niech szwiec swego patrzy kopyta [lit. A shoemaker should mind his own last].

The disrespectful attitude towards shoemakers is confirmed by other word combinations, not mentioned by Troc but functioning in the common Polish language, e.g. Szewcy, krawcy, nie ludzie (NKP, 1970, p. 394) [lit. Shoemakers, tailors are not people]; Szewiec a świnia to jedna rodzina (NKP, 1972, p. 395) [lit. A shoemaker and a pig are one family]; Szewc to pierwszy po hyclu (NKP, 1972, p. 394) [lit. A shoemaker is first after a dog catcher]; Leci jak szewc z butami na jarmark (NKP, 1972, p. 393) [lit. He runs like a shoemaker with shoes to the market]; Szewc im lepszy majster, tym gorszy pijak (NKP, 1972, p. 394) [lit. The more expert the shoemaker, the more of a drunkard]; Między rzemieślniki największe łgarze szewcy (NKP, 1972, p. 395) [lit. Among the craftsmen, the greatest liars are shoemakers].

In past centuries contempt for shoemakers was common. They were perceived as unreliable and unpunctual craftsmen (Adalberg, 1889-1894, p. 541), looking for extra income outside their trade and dealing with matters they knew nothing about (Krasnowolski, 1905, pp. 19-23). Besides, they were associated with the skinning of dead horses (Krzyżanowski, 1994, p. 219). The Polish ethnographer Jan Bystron explains the low position and dismissive attitude towards shoemakers with the fact that, in the past, the manufacturing and repairing of footwear were done by the physically weak or the disabled, who could not perform occupations requiring physical fitness (Bystron', 1933, pp. 107-108).

In the proverb Niech szwiec swego patrzy kopyta [lit. A shoemaker should mind his own last], the most characteristic tool associated with a shoemaker has also been preserved. The term kopyto 'shoemaker's last' is used not only to identify the occupation of the craftsman, but also as the synecdoche of the craft (Młynarczyk, 2012,

image elements, their hierarchical arrangement and "focal adjustment" (cf. Langacker, 1987, 1991, 2008). According to Langacker (1999, p. 203), our (mental) perception of the world is the outcome of prior experience and it is to some degree biased, as there is no neutral, omniscient or aloof observer.

${ }^{2}$ For reasons of space, entry words are marked in bold. 
p. 143). This is indicated, among others, by the equivalence of the components such as craft (rzemiosło) and shoemaker's last (kopyto) in both variants of the proverb.

\subsection{Blacksmiths and wheelwrights}

The proverbs containing the occupations blacksmith (kowal) and wheelwright (kołodziej) are not only carriers of historical and cultural content, but, primarily, illustrate the fact that craftsmen were distinctive members of communities, especially in small towns like Osiek, symbolizing the fools' habitat. This is illustrated by the proverbs in Troc's dictionary: Osieckie prawo: kowal zgrzeszył a kołodzieja powieszono [lit. Osiek law: the blacksmith sinned, but the wheelwright was hanged]. The proverbs also emphasize the characteristic activity of the craft: Kto rozumu nie ma i kowal go nie ukuje [lit. Someone who has no reason can't get a blacksmith to forge it].

\subsection{Cooks}

Another occupation documented in eighteenth-century proverbs is a cook (kucharz): Kucharz głodem nie umrze [lit. A cook will not die of hunger]. In this proverb, revealing the qualities of high resourcefulness, cunning nature and practicality attributed to the cook, we can see the negative assessment of the occupation. In the past, when starvation was widespread, a resourceful cook was not only replete, but also - as Bystron describes - able to make a substantial fortune, which is why cooks had the reputation of drunkards and thieves (Bystroń, 1960b, p. 488).

\subsection{Doctors}

It seems that doctors, whose assessment is ambivalent, are ranked between craftsmen of low position and magnates of high position. The proverbs of the eighteenth century mostly refer to their incompetence, lack of professional knowledge and dilettantism, for example: Bez księgi doktor nie tegi [lit. Without a book a doctor has no might]; Niedoskonały lekarz pewnym bywa zabojca [lit. A poor doctor can be a certain killer]; Lekarza o zaboj nie pozywaja [lit. Doctors don't get sued for killing].

The picture of an ignorant, poorly educated doctor recorded in proverbs is confirmed by cultural sources. Zbigniew Kuchowicz (Kuchowicz, 1975, pp. 107-130) provides many examples of pseudo-doctors, charlatans, healers, miracle-workers 
and quacks who came from far away and tried to cure various diseases using magical methods and miraculous mixtures. Naturally, patients who were tempted with the promise of successful treatment used their services because many serious diseases were widespread among the population in the seventeenth and eighteenth centuries: the plague, smallpox, typhus, marsh fever, syphilis and others. People affected by wars, malnutrition, poor hygiene, but also by dissolute lifestyles (especially at magnate courts), were prone to illnesses which were incurable due to the stage of development of medicine at the time. Bystron concludes that even though there were many physicians, the level of their knowledge and skills was very low. The level of the whole medical education system in Poland in the first half of the eighteenth century was similar to that of the seventeenth century. For example, the medical faculty of the Cracow Academy barely subsisted from the seventeenth century: there were no funds, professors or even students. The medical faculty at the Academy in Zamość did not have a single professor of medicine for the entire half of the eighteenth century. The first medical school in Warsaw was established only in 1789 . As studying abroad was expensive, medical treatment was provided by doctors who acquired practical skills, learning from their experienced colleagues as well as barber-surgeons, pharmacists and self-taught doctors, whose knowledge was based on the observation of various diseases and treatments (Bystroń, 1960a, pp. 423-425).

In spite of this unflattering image, Nowy dykcjonarz also records a proverb that recommends treating a doctor with respect: Lekarza trzeba szanować [lit. A doctor should be respected]. However, in its full version, the proverb includes a warning: Lekarza trzeba szanować, boć się też trafi chorować [lit. A doctor should be respected because illness can happen (to you)], indicating that this rule was motivated only by egotistic needs.

\subsection{Executioners}

Three proverbs give the idea of the position of an executioner (kat) in Polish society of the eighteenth century. The first: Dwaj kaci (kacia) w jednym miasteczku się nie pożywia [lit. Two executioners in one small town will not be able to feed themselves], informs us that it was a rare occupation due to the limited demand for this kind of service in peacetime. Two more proverbs: Duzssy słabszemu często bywa katem [lit. The stronger is often an executioner to the weaker], and Złe sumnienie za kata stoi [lit. A bad conscience is like an executioner], activate the figurative meanings, emphasize the connotation 
of the word kat 'executioner', strongly rooted in language and culture, such as 'cruelty', 'inflicting suffering', 'execution of a sentence', 'death'. The context of the word kat in both proverbs implies the low status of executioners, which is consistent with historical and cultural knowledge. An executioner was a despised man who evoked extreme disgust because he had blood on his hands by his own choice. In the past, his occupation made him unclean, like slaughterers, gravediggers, dog catchers, street cleaners and prostitutes, and aroused fear and hostility. At the sight of an executioner, people turned away their heads and spat with contempt (Tokarczyk, 2011, p. 70).

\section{The Social context of the eighteenth century}

To get a broader picture of daily life in eighteenth-century Poland, one also has to take a look at those in manor houses living in extravagance, splendour, prodigality, and with a passion for luxury (cf. Wiśniewska, 2009, pp. 247-248). Bystron's description of opera performer groups can testify to the lavishness and splendour of magnates and their courts (Bystroń, 1960b, p. 265). In the eighteenth century, some of them kept operas and ballets in their palaces to dazzle their guests with grand performances. This sharp contrast in the feudal society is reflected in the language. From the perspective of a big city, a great lord and his lifestyle were much more visible than a blacksmith or shoemaker, and hence he is a component of many proverbs recorded by Troc, for example: Nowy pan, nowy rzad [lit. A new master, a new government]; Jaki pan, taki kram [lit. What is the master, such is the stall]; Kazat pan, musiat sam [lit. The master gave an order but had to execute it himself]; Laska pańska na pstrym koniu jeździ [lit. Master's mercy rides on a motley horse]; Pan drze chtopa jako skopa, a diabeł Pana jak barana [lit. The lord rips a peasant off like a castrated sheep and the devil rips a lord off like a ram]; Prośba pańska rowno z nakazem chodzi [lit. The master's request is an order]; Pańska prośba za rozkazanie stoi [lit. The master's request stands for an order]; Oko pańskie konia tuczy [lit. The master's eye makes the horse fat]; Oko pańskie w każdy kat zaglada [lit. The master's eye looks into every corner]; Pańskie niedojadki dobre dla czeladki [lit. The master's leftovers are good for the servants].

It seems that the court life of the high and mighty was an object of careful observation because various aspects of this life are reflected in proverbs, for example, the requirement for the courtiers to own property: Błogo temu przy 
dworze, komu doma plug orze [lit. Blissful are those at a court whose own fields are ploughed]; hypocrisy, insincerity and arrogance characteristic of courtly life: $U \boldsymbol{d}$ woru niemasz kandoru [lit. There is no candour at the court], Prawda i pokora nie znajdzie miejsca $u$ dwora [lit. There is no place for truth and humbleness at the court]; miserliness of the powerful: Dworska odprawa $z$ gołemi reckoma [lit. The court's farewell with empty hands]; the greater importance of attire than the attributes of the spirit: $U \boldsymbol{d} w o r u$ pstro, ale mdło [lit. The court is motley but bland]. Following the trends in fashionable clothes was particularly evident in the Saxon era. The magnificence of the attire manifested itself in the originality of the cut, selection of expensive fabrics, bright colours, richness of ornaments, all of which were a token of financial and social status (cf. Kuchowicz, 1975, p. 297). This is perfectly reflected in the proverb Jakie odzienie, takie raczenie [lit. What the clothes are such is the reception]. The high social status of the magnates found an adequate reflection in the language, as can be seen from the examples presented above.

\section{Discussion}

The analysis so far shows that among nearly eight hundred proverbs from the dictionary Nowy dykcjonarz only a few are structures with the names of craftsmen, compared to the great number of proverbial references to craftsmen in today's Polish language. ${ }^{3}$ What are the reasons for this? First of all, proverbs in the dictionary by Troc have a functionalized character: they serve as an illustration of the entry words and sub-entries (cf. Kuryłowicz, 2016, pp. 183-194). It seems that it is not a matter of chance that proverbs belonging to different thematic circles have a diversified, asymmetric representation in the dictionary. For example, some proverbs with names of values, including wisdom and reason, are recorded in large numbers, while others, such as proverbs with names of craftsmen, occur incidentally. Such a selection and thematic layout of proverbs, firstly, forms part of the overall methodological concept of the dictionary; secondly, it is justified by the way of viewing the world contained in the work.

3 Analysing craft phraseology and proverbs, Ewa Młynarczyk writes about 390 units she collected with a component in the form of a craft trade name or an adjective derived from the name, of which the most (69) were those with the components szewc 'shoemaker' and szewski 'shoemaker's' (Młynarczyk, 2015, p. 173). 
Troc, a Polish language teacher at the University of Leipzig, translator of poetry, collaborator of the Załuski brothers in arranging their library, and Polish language enthusiast (cf. Iwanowska, 1994, pp. 291-292; Urbańczyk, 1979, p. 295; Walczak, 1994, p 52), certainly gathered the lexical material with great care and deliberately placed it in the dictionary. The aim of the lexicographer was to show the richness and beauty of the Polish language, and, thereby, to give the language greater importance in the life of the nation. Additionally, he had an aspiration to prove that the collective thought, the mental state of Polish society and the achievements of Polish science were at a high level and could be successfully described in Polish (cf. Kuryłowicz, 2016, pp. 183-194). In the preface to Nowy dykcjonarz (Troc, 1764, k. a4r), entitled "Łaskawy Czytelniku" [Dear Reader], he argued that apart from words in three languages and colloquial lexis and proverbs, he included scientific vocabulary in the lexicon. This was supposed to prove to jealous doubters that the Polish language was able to handle the scientific sphere of life and that a language is a mirror in which scientific achievements of a nation are reflected. This part of the preface says a lot about Troc's understanding of the important role of a language in the culture of a nation. The lexicographer perceived language not only as a communication tool, but also as a carrier of the collective experience and outlook on life. This belief could have an impact on extending the purpose and intention of the dictionary and developing its basic function as an aid in learning the Polish language, which is why the cultural aspect was also considered. Troc's idea was to endow the dictionary with the value of a work that is a record of the Polish cultural code, manifested in language units. For this reason, such entries as blacksmith, furrier, shoemaker, tailor, etc., due to a common understanding and good knowledge of their designates by language users of the time, include very modest illustrative material and do not feature many proverbs. In a few structures with a craft component, the names "blacksmith", "wheelwright" or "shoemaker" and their expressive, conventionalized connotations serve to build specific images. Those images cognitively express complex contents in a simple and distinct manner, for example, abstract concepts, interpersonal, social and moral relations.

The second reason for the low frequency of proverbs with the names of occupations, including craftsmen, in Nowy dykcjonarz is related to the way of perceiving the eighteenth-century Polish reality recorded in the lexicon, and stems from seeing the world from the perspective of a big city. Krystyna Siekierska (Siekierska, 1992, pp. 259-268), who studied the description of reality in the dictionaries by Knapiusz and Troc, observes that in Nowy dykcjonarz there 
is a reflection of the sphere of everyday existence (including attire, apartment furnishing, food, work, entertainment, family relations, etc.) which is typical of a big city. She also notes that the everyday life of a big city permeates into the dictionary, and that Troc knew the Polish reality perfectly well, although he wrote his dictionary in Leipzig.

In the eighteenth-century Polish reality shown from the perspective of a big city, craftsmen were pushed to the background. In a big city, a blacksmith, a miller or a wheelwright were invisible figures, supporting actors, people who performed admittedly important service functions behind the scenes of glamorous court life, providing aristocracy with a comfortable life, but still, they only provided service. ${ }^{4}$ In the Saxon era in Poland, people of low status were despised, since doing nothing was in high regard at the time (Wiśniewska, 2009, p. 150); hence the negative perception of tailors, shoemakers, merchants in the moral culture and in the language, which reflects culture. The economic and social situation in the Saxon era was not without an influence on the negative image of craftsmen.

The impoverishment and decline of society had progressed since the beginning of the century. The peasantry, the burghers and the gentry were growing poorer. In cities with a guild, there were often only two masters, and craftsmen peddled from village to village with necessities because there was no market for their goods due to the crisis of consumption and decreasing prices. There were situations when master craftsmen, for example from Przemyśl, went to local markets to beg to support themselves and their families (cf. Wiśniewska, 2009, pp. 245-246).

\section{Conclusion}

The considerations presented above allow for a more general conclusion concerning the methodology of reconstruction of the linguistic worldview from the past on the basis of language material included in a historical dictionary. It is assumed that a good, reliable source for such research should meet the following criteria: it should come from one author living in the period from which the material originates; the lexicographer should display the powers of

${ }^{4}$ Craftsmen played a greater role in small towns and villages, where they were clearly present, hence a considerable number of proverbs with a craft component belong to dialectal varieties of Polish. 
observation, good intuition and high linguistic awareness; the material should reflect accurately the lexical resource of the period covered by the dictionary (cf. Kuryłowicz, 2018; Siekierska, 1992).

It seems that apart from these features it is necessary to take into account the intentions that motivated the lexicographer in the course of his work and the attendant picture of reality, which depends on this important factor. Both factors (the intention, which is part of the general concept of the dictionary, and the perspective of the worldview) have a significant impact on the frequency, structure and manner of presenting the vocabulary in Nowy dykcjonarz. Not only was Troc interested in showing everyday life (in a big city), reflected in colloquial lexis, but also in emphasizing the intellectual, mental and psychological sphere of Polish society. Hence scientific terms, specialist vocabulary, abstract words naming moral attitudes, values, social behaviours, features of the mind, attitudes towards life, attitude to work and other essential properties, and hence those areas of life that create the spiritual culture of a nation, which are a significant part of the Polish-language dictionary material. The immaterial sphere of life and ways of thinking about the surrounding reality have a strong representation also in proverbs (cf. Kuryłowicz, 2017).

The image of the eighteenth-century Polish reality emerging from the linguistic material of Nowy dykcjonarz is not a result of a bird's eye view or global perception of the world. We are more likely dealing with profiling, ${ }^{5}$ which involves displaying those parts of contemporary life that are important from the perspective of the lexicographer, and at the same time shifting to the background those areas that are less culturally important. The profiling in question is conditioned by the intention, object and purpose of the dictionary as well as the viewpoint and the big-city perspective adopted by the author. Taking into consideration all of these factors helps us understand better the fact that the limited exposition of craftsmen and other occupations in the language of Nowy dykcjonarz does not mean they were absent from public life. This is a result of low social rank of working people in the Saxon era in Poland and the effect of shifting the centre of gravity from the concrete, material sphere of life towards a more mental and spiritual one.

5 The terms: profiling, viewpoint and ground distinction are used as defined by Langacker. Profiling is a dimension of imagery. It consists in giving salience, highlighting a given element within a base. The figure-ground perception and viewpoint constitute substructures of perspective (Langacker, 1987, pp. 120-122). 
B. Kuryłowicz, K. K. Szamryk ～Linguistic and Cultural Perceptions of Selected Occupations...

\section{Abbreviations}

NKP - Nowa księga przysłów i wyrażeń przysłowiowych polskich (Krzyżanowski, 1970, 1972).

\section{References}

Adalberg, S. (1889-1894). Księga przysłów, przypowieści i wyrażeń przysłowiowych polskich. Drukarnia Emila Skiwskiego.

Allwood, J. (2004). Språk och världsbilder. In C. Ilie (Ed.), Language, culture, rhetoric: Cultural and rhetorical perspectives on communication: Papers from the ASLA symposium in Örebro, 6-7 November 2003 (pp. 21-35). Association Suédoise de Linguistique Appliquée.

Anusiewicz, J. (1994). Lingwistyka kulturowa: Zarys problematyki. Wydawnictwo Uniwersytetu Wrocławskiego.

Bartmiński, J. (2012). Aspects of cognitive ethnolinguistics. Equinox.

Bystroń, S. (1933). Przysłowia polskie. Polska Akademia Umiejętności.

Bystroń, S. (1960a). Dzieje obyczajów w dawnej Polsce: Wiek XVI-XVIII (Vol. 1). Państwowy Instytut Wydawniczy.

Bystroń, S. (1960b). Dzieje obyczajów w dawnej Polsce: Wiek XVI-XVIII (Vol. 2). Państwowy Instytut Wydawniczy.

Fillmore, J. (1979). Topics in lexical semantics. In R. W. Cole (Ed.), Current issues in linguistic theory (pp. 79-183). Indiana University Press.

Fillmore, J. (1982). Frame semantics. In Linguistics in the morning calm: Selected papers from SICOL-1981 (pp. 111-137). Hanshin Publishing Company.

Fillmore, J. (1985). Frames and the semantics of understanding. Quaderni di Semantica, 1985(6(2)), 222-254.

Hołówka, T. (1986). Myślenie potoczne: Heterogeniczność zdrowego rozsądku. Państwowy Instytut Wydawniczy.

Iwanowska, A. (1986). Wyrazy “żeglarskie” w dykcjonarzach Michała Abrahama Troca: Kilka uwag o kształtowaniu się polskiej leksyki morskiej XVIII w. Zeszyty Naukowe Wydziału Humanistycznego Uniwersytetu Gdańskiego: Prace Językoznawcze, 1986(12), 43-86.

Iwanowska, A. (1989a). Michał Abraham Troc i bracia Załuscy. Kwartalnik Historii Nauki i Techniki, 34(2), 237-260.

Iwanowska, A. (1989b). Troc czy Trotz? (Część 1). Studia z Filologii Polskiej i Słowiańskiej, 25, 17-29. Iwanowska, A. (1990). Troc czy Trotz? (Część 2). Studia z Filologii Polskiej i Słowiańskiej, 26, 25-39. Iwanowska, A. (1991a). Praca Michała Abrahama Troca nad słownictwem morskim. Gdańskie Studia Językoznawcze, 1991(5), 31-58. 
B. Kuryłowicz, K. K. Szamryk ～Linguistic and Cultural Perceptions of Selected Occupations...

Iwanowska, A. (1991b). O definicjach słownikowych w Nouveau dictionnaire françois, allemand et polonois Michała Abrahama Troca. Studia z Filologii Polskiej i Słowiańskiej, 28, 5-22.

Iwanowska, A. (1993a). Michał Abraham Troc w kulturze naukowej lat czterdziestych XVIII w. Kwartalnik Historii Nauki i Techniki, 38(3), 35-60.

Iwanowska, A. (1993b). Michał Abraham Troc - lektor języka polskiego w Lipsku. Zeszyty Naukowe Wydziału Humanistycznego Uniwersytetu Gdańskiego: Prace Historycznoliterackie: Oświecenie: Studia i szkice, 1993(16), 73-85.

Iwanowska, A. (1994). O metodzie leksykograficznej Nowego dykcyjonarza to jest mownika polsko-niemiecko-francuskiego (1764) Michała Abrahama Troca. Prace Filologiczne, 39, 291-325.

Jędrzejko, E. (2015). Przysłowia, aforyzmy, sentencje...: Jeden gatunek czy różne gatunki? In D. Ostaszewska \& J. Przyklenk (Eds.), Gatunki mowy i ich ewolucja: Vol. 5. Gatunek a granice (pp. 151-160). Wydawnictwo Uniwersytetu Śląskiego.

Krasnowolski, A. (1905). Przenośnie mowy potocznej. Wydawnictwo M. Arcta.

Krzyżanowski, J. (1994). Mądrej głowie dość dwie słowie: Pięć centuryj przysłów polskich i diabelskich tuzin z hakiem. Państwowy Instytut Wydawniczy.

Krzyżanowski, J. (Ed.). (1970). Nowa ksiega przysłów i wyrażeń przysłowiowych polskich [NKP]. Państwowy Instytut Wydawniczy.

Krzyżanowski, J. (Ed.). (1972). Nowa ksiegga przysłów i wyrażeń przysłowiowych polskich [NKP]. Państwowy Instytut Wydawniczy.

Kuchowicz, Z. (1975). Obyczaje staropolskie XVII-XVIII wieku. Wydawnictwo Łódzkie.

Kuryłowicz, B. (2014). Osiemnastowieczne przysłowia w Nowym dykcjonarzu M. A. Trotza z perspektywy współczesnej. Białostockie Archiwum Językowe, 2014(14), 39-51. https:// doi.org/10.15290/baj.2014.14.03

Kuryłowicz, B. (2016). Przysłowia w Nowym dykcjonarzu Michała Abrahama Trotza. Prace Filologiczne, 68, 183-194.

Kuryłowicz, B. (2017). Przysłowia jako źródło wiedzy o osiemnastowiecznej kulturze duchowej Polaków: Na przykładzie Nowego dykcjonarza Michała Abrahama Troca. Poradnik Językowy, 2017(5), 55-64.

Kuryłowicz, B. (2018). Słownik historyczny jako źródło do rekonstrukcji dawnych sposobów myślenia o świecie. In M. Pastuch \& M. Siuciak (Eds.), Historia języka w XXI wieku: Stan i perspektywy (pp. 277-286). Wydawnictwo Uniwersytetu Śląskiego.

Lakoff, G. (1986a). Cognitive semantics. Versus: Quaderni di Studi Semiotici, 1986(44-45), 119-154.

Lakoff, G. (1986b). Classifiers as a reflection of mind. In C. Craig (Ed.), Noun classes and categorization (pp. 13-51). John Benjamins Publishing Company. https://doi.org/10.1075/tsl.7.04lak

Langacker, R. W. (1987). Foundations of cognitive grammar: Vol. 1. Theoretical prerequisites. Stanford University Press.

Langacker, R. W. (1991). Foundations of cognitive grammar: Vol. 2. Descriptive applications. Stanford University Press. 
B. Kuryłowicz, K. K. Szamryk ～Linguistic and Cultural Perceptions of Selected Occupations...

Langacker, R. W. (1999). Grammar and conceptualisation. Mouton de Gruyter. https://doi.org $/ 10.1515 / 9783110800524$

Langacker, R. W. (2008). Cognitive grammar: A basic introduction. Oxford University Press. https://doi.org/10.1093/acprof:oso/9780195331967.001.0001

Młynarczyk, E. (2012). Wybrane historycznokulturowe aspekty frazeologii rzemieślniczej. Studia Językoznawcze, 2012(11), 137-150.

Młynarczyk, E. (2013). Nie święci garnki lepią: Obraz rzemiosła utrwalony w polskiej frazeologii. Uniwersytet Pedagogiczny im. Komisji Edukacji Narodowej w Krakowie.

Młynarczyk, E. (2015). Polska frazeologia rzemieślnicza - problematyka i założenia opisu. In D. Bralewski (Ed.), Problemy Frazeologii Europejskiej X (pp. 167-180). Oficyna Wydawnicza LEKSEM.

Puzynina, J. (1993). Obraz świata w dziele leksykograficznym M. A. Troca (1764). In I. Kunert (Ed.), Studien zur polnischen Literatur-, Sprach- und Kulturgeschichte im 18. Jahrhundert: Vorträge der 3. deutsch-polnischen Polonistenkonferenz, Tübingen, April 1991 (pp. 71-87). Böhlau Verlag.

Siekierska, K. (1992). Rzeczywistość w słownikach Knapiusza i Troca. Prace Filologiczne, 1992(37), 259-268.

Skorupka, S. (1985). Przysłowia a wyrażenia i zwroty przysłowiowe. Prace Filologiczne, 1985(32), 359-364.

Stefanović, M. (2009). O poslovicama u proučavanju jezičke slike sveta (na materijalu ruskog i srpskog jezika). Godišnjak Filozofskog fakulteta u Novom Sadu, 34(1/2), 31-42.

Szpila, G. (2003). Krótko o przysłowiu. Collegium Columbinum.

Taylor, J. (1989). Linguistic categorization: Prototypes in linguistic theory. Oxford University Press.

Tokarczyk, R. (2011). Tortury i egzekucja w etyce kata. Etyka Praktyczna, 2011(2), 55-77.

Tokarski, R. (2013). Światy za słowami: Wykłady z semantyki leksykalnej. Wydawnictwo Uniwersytetu Marii Curie-Skłodowskiej.

Troc, M. A. (1764). Nowy dykcjonarz, to jest mownik polsko-niemiecko-francuski z przydatkiem przysłow potocznych, przestrog gramatycznych, lekarskich, matematycznych, fortyfikacyjnych, żeglarskich, łowczych i inszym naukom przyzwoitych wyrazow przez Michała Abrahama Troca, warszawianina. Drukarnia Jana Fryderyka Gledycza.

Underhill, J. (2009). Humboldt, worldview and language. Edinburgh University Press. https://doi.org /10.3366/edinburgh/9780748638420.001.0001

Urbańczyk, S. (1979). Prace z dziejów języka polskiego. Zakład Narodowy im. Ossolińskich.

Walczak, B. (1994). Nowe prace o polskich słownikach osiemnastowiecznych. In H. Misterski \& J. Sypnicki (Eds.), Studia romanica in honorem Stanislai Gniadek (pp. 45-57). Wydawnictwo Poznańskiego Towarzystwa Przyjaciół Nauk.

Wiśniewska, H. (2009). Polszczyzna przez wieki. Wydawnictwo Wyższej Szkoły Humanistyczno-Ekonomicznej.

Wyżkiewicz-Maksimow, R. (2012). Językowy obraz człowieka: Charakter i osobowość w paremiologii polskiej, serbskiej i chorwackiej. Wydawnictwo Uniwersytetu Gdańskiego. 


\title{
Linguistic and Cultural Perceptions of Selected Occupations in Eighteenth-Century Proverbs (on the Basis of Nowy dykcjonarz by Michał Abraham Troc)
}

\author{
Summary
}

This paper is an attempt to show the possibilities offered by an analysis of a historical dictionary in researching the old ways of perceiving, categorizing and evaluating the world. The observations in question are based on proverbs extracted from Nowy dykcjonarz by Michał Abraham Troc, which is one of the most significant achievements of Polish lexicography of the eighteenth century.

Using the methodology of linguistic worldview reconstruction, the authors present the ways of perceiving certain occupations (shoemakers, blacksmiths, wheelwrights, cooks, doctors, executioners) by people in the eighteenth century and provide the cultural context of these perceptions. The analysis demonstrates that language is not only a communication tool, but also a carrier of the collective experience and outlook on life.

\section{Językowa i kulturowa percepcja wybranych zajęć w XVIII-wiecznych przysłowiach (na materiale Nowego dykcjonarza Michała Abrahama Troca)}

\section{Streszczenie}

Celem niniejszego tekstu jest wskazanie możliwości, jakie daje analiza słownika historycznego w badaniu dawnych sposobów postrzegania, kategoryzowania i wartościowania świata. Rozważania te opierają się na przysłowiach zaczerpniętych z Nowego dykcjonarza Michała Abrahama Troca. Słownik ten jest jednym z najważniejszych osiągnięć polskiej leksykografii XVIII wieku. 
Posługując się metodologią językowego obrazu świata, autorzy rekonstruują językowo-kulturowy sposób postrzegania zawodów (szewców, kowali, kołodziejów, kucharzy, lekarzy, katów) utrwalony w osiemnastowiecznych przysłowiach. Przedstawiona analiza dowodzi, że język jest nie tylko narzędziem komunikacji, ale także nośnikiem zbiorowego doświadczenia i poglądu na świat.

Keywords: lexicography; proverbs; Polish language of the 18th century; Michael Abraham Trotz; Polish culture of the 18th century

Słowa kluczowe: leksykografia; przysłowia; polszczyzna XVIII wieku; Michał Abraham Troc; kultura polska w XVIII wieku

(1) Beata Kuryłowicz, University of Białystok, Białystok, Poland

ORCID: http://orcid.org/0000-0003-2309-4313

Correspondence: b.kurylowicz@uwb.edu.pl

(2) Konrad Kazimierz Szamryk, University of Białystok, Białystok, Poland ORCID: http://orcid.org/0000-0002-0910-1209

Correspondence: k.szamryk@uwb.edu.pl

Authors' contribution: Beata Kuryłowicz is responsible for the conception of the study and data collection, Konrad Szamryk developed the material. Both authors co-authored the original text of the article.

The preparation of this article was financed from a grant received from the Polish Ministry of Science and Higher Education under the Regional Initiative of Excellence programme for the years 2019-2022, project number 009/RID/2018/19, the amount of funding: PLN 8,791,222.00.

Competing interests: The authors have declared they have no competing interests.

Publication history: Received: 2020-07-22; Accepted: 2021-02-02; Published: 2021-11-30 